\title{
Inferred calcification rate of a temperate azooxanthellate caryophylliid coral along a wide latitudinal gradient
}

\author{
E. Caroselli ${ }^{1}$ - V. Brambilla ${ }^{1}$ F. Ricci ${ }^{1} \cdot$ G. Mattioli $^{2}$ \\ O. Levy ${ }^{3}$ - G. Falini ${ }^{4} \cdot$ Z. Dubinsky ${ }^{3} \cdot$ S. Goffredo ${ }^{1}$
}

Received: 22 April 2015/Accepted: 10 February 2016/Published online: 23 February 2016

(c) Springer-Verlag Berlin Heidelberg 2016

\begin{abstract}
Correlations between environmental parameters (depth temperature and solar radiation) and growth parameters (bulk skeletal density, linear extension rate and net calcification rate) of the solitary azooxanthellate coral, Caryophyllia inornata, were investigated along an $8^{\circ}$ latitudinal gradient on the western Italian coasts. Net calcification rate correlated positively with both bulk skeletal density and linear extension rate, showing that $C$. inornata allocates calcification resources evenly to thickening the skeleton and increasing linear growth. Overall, the three growth parameters did not follow gradients in the two environmental parameters, showing a different trend compared to most studies on zooxanthellate corals. However, the results are in agreement with the only previous analysis of an azooxanthellate coral, Leptopsammia pruvoti, studied along the same latitudinal gradient. In a comparison of the response to temperature of all Mediterranean species whose growth has been investigated to date, azooxanthellate corals were more tolerant to temperature increases than zooxanthellate corals.
\end{abstract}

Communicated by Biology Editor Dr. Mark J.A. Vermeij

S. Goffredo

s.goffredo@unibo.it

1 Marine Science Group, Department of Biological, Geological and Environmental Sciences, University of Bologna, Via F. Selmi 3, 40126 Bologna, Italy

2 Operative Unit of Radiology and Diagnostics by Images, Hospital of Porretta Terme, Local Health Enterprise of Bologna, Via Roma 16, 40046 Porretta Terme, Italy

3 The Mina and Everard Goodman Faculty of Life Sciences, Bar-Ilan University, Ramat Gan 52900, Israel

4 Department of Chemistry "Giacomo Ciamician", University of Bologna, Via F. Selmi 2, 40126 Bologna, Italy
Keywords Global warming $\cdot$ Net calcification - Linear extension - Skeletal density - Caryophyllia inornata . Scleractinia

\section{Introduction}

Temperature and solar radiation (SR), both strongly influenced by latitude, are fundamental in determining the global distribution of scleractinians (Kleypas et al. 1999). Additionally, these same parameters have a wide number of implications for coral physiology, demography, reproduction and distribution patterns (Kleypas et al. 1999; Coma et al. 2000; Reynaud et al. 2003; Goffredo and Lasker 2008; Goffredo et al. 2008; Airi et al. 2014). Ongoing climate change, through global warming and ocean acidification, poses serious threats to coral reef ecosystems and causes increased mass coral bleaching and alterations in some ecological processes (Hoegh-Guldberg 2011). For example, recruitment is a key process strongly influenced by climate variability, as are primary and secondary production, causing repercussions in food chains, migrations and spatial distributions of organisms (Walther et al. 2002). Coral growth is another mechanism that is threatened by climate change. For example, the net calcification rate of Porites sp. on the Great Barrier Reef (Cooper et al. 2008) and in Thailand (Tanzil et al. 2009) has decreased with increasing sea surface temperature (SST) in the last 16-21 yr. In the Red Sea, ocean warming is slowing the net calcification rate of Diploastrea heliopora (Cantin et al. 2010). Even though SST variations in space (e.g., along a latitudinal gradient) are not equivalent to ocean warming through time (Kleypas et al. 2005; Lough and Cantin 2014), spatial temperature gradients have been used to infer the response of species to rising 
temperatures. In Porites sp. living in the Hawaiian archipelago, in Thailand and on the Great Barrier Reef, net calcification rate increases with SST (Lough and Barnes 2000). In the Mediterranean Sea, the colonial zooxanthellate coral Cladocora caespitosa increases its net calcification rate with SST along a natural temperature gradient (Kružić et al. 2012), but laboratory observations showed that long-term exposure to high temperature led to a decrease in net calcification (Rodolfo-Metalpa et al. 2006). The net calcification rate of another zooxanthellate but solitary Mediterranean coral, Balanophyllia europaea, correlated negatively with increasing SST along a natural temperature gradient on the western Italian coast (Goffredo et al. 2009), while the net calcification rate of the solitary azooxanthellate coral Leptopsammia pruvoti did not vary along the same gradient (Caroselli et al. 2012). Interest in the repercussions of SR on coral biology, physiology and ecology is increasing (Shick et al. 1996; Brown et al. 2000; Anthony and Kerswell 2007). This parameter is a possible regulator of the growth of Porites sp., even if SST is the primary control (Lough and Barnes 2000).

Calcification is an energy-consuming physiological process in which the maximum rate can be reached when environment conditions are optimal (Marshall and Clode 2004). Optimal conditions vary with species (CarricartGanivet et al. 2012). As a consequence, correlations between temperature (or SR) and calcification can show whether environmental variation influences the growth of a particular species positively or negatively, thus moving environmental conditions toward or away from the calcification optimum. It is then possible to project the likely effects of global climate change on scleractinian growth and calcification (Cooper et al. 2008; Tanzil et al. 2009; Cantin et al. 2010).

Coral growth is described by three parameters: linear extension rate $\left(\mathrm{mm} \mathrm{yr}^{-1}\right)$, bulk skeletal density $\left(\mathrm{mg} \mathrm{mm}^{-3}\right)$ and net calcification rate $\left(\mathrm{mg} \mathrm{mm}^{-2} \mathrm{yr}^{-1}\right)$, obtained by multiplying the former two (Dodge and Brass 1984; Lough and Barnes 2000; Carricart-Ganivet 2004; Goffredo et al. 2009; Tanzil et al. 2009; Cantin et al. 2010; Caroselli et al. 2012). The measurement of all three growth components is fundamental when assessing the effect of the environment on coral growth, since none of the three is a perfect predictor of the other two (Dodge and Brass 1984) and each one can respond differently to environmental conditions (Lough and Barnes 2000; Carricart-Ganivet 2004; Goffredo et al. 2009; Tanzil et al. 2009; Caroselli et al. 2012). Each scleractinian may adopt a different growth strategy, for example, by preferentially investing calcification resources in bulk skeletal density while sacrificing linear extension, as done by Orbicella annularis (formerly Montastraea annularis, Budd et al. 2012) in the southern Gulf of Mexico with the 'stretching modulation of skeletal growth' (Carricart-
Ganivet and Merino 2001; Carricart-Ganivet 2007). In contrast, Porites invests calcification resources in linear extension (Lough and Barnes 2000). Investing in thicker skeletons may imply a greater resistance to mechanical stresses, while increasing the linear extension rate may be advantageous in the competition for space (Goffredo et al. 2009; Caroselli et al. 2012) and for the achievement of sexual maturity, which in solitary corals is reached at a certain size, depending on the species (Goffredo et al. 2008; Airi et al. 2014). As a result, environmental variations can have a wide range of implications on coral growth patterns, depending on the species.

While studies on the relationship between coral growth and environmental parameters in the tropics are numerous, such studies are scarce for temperate zones (Howe and Marshall 2002; Caroselli et al. 2012). The species involved in the present study is the temperate-subtropical azooxanthellate coral Caryophyllia inornata (Duncan, 1878). All species of the genus Caryophyllia are solitary, including $C$. inornata, which is present in the Mediterranean basin and in the eastern Atlantic Ocean from the Canary Islands to the southern coasts of Great Britain (Zibrowius 1980). Caryophyllia inornata colonizes vaults of caves and crevices, walls and wrecks from the surface to $100 \mathrm{~m}$ depth, and it can be a very common species in some overhangs (Zibrowius 1980). It is a gonochoric brooding species and has unusual embryogenesis with possible agamic production of embryos (Goffredo et al. 2012a). Sexual maturity is reached at a size of $\sim 6.1 \mathrm{~mm}$ (Marchini et al. 2015), corresponding to $\sim 7$-yr-old polyps. Its abundance and age-length relationship are homogenous along the western Italian coast, while demographic parameters indicate less stable populations and juvenile deficits with increasing SR (i.e., going southward; Caroselli et al. 2016).

This study aimed to understand the growth strategy of $C$. inornata by investigating the relationships between the three growth parameters (bulk skeletal density, linear extension rate and net calcification rate) and depth temperature (DT) and SR.

\section{Materials and methods}

Specimens of $C$. inornata were collected at six sites along a latitudinal gradient on the western Italian coasts, from $44^{\circ} 20^{\prime} \mathrm{N}$ to $36^{\circ} 45^{\prime} \mathrm{N}$ (Fig. 1), between 14 May 2009 and 14 April 2011. At each site, samples were collected using transects that consisted of 4-8 square patches of $0.1 \mathrm{~m}^{2}$ each, $3 \mathrm{~m}$ apart (site and number of patches: Genova: $n=4$; Calafuria: $n=8$; Elba: $n=4$; Palinuro: $n=6$; Scilla: $n=6$; and Pantelleria: $n=7$ ). The sampling was performed within a depth range (11-16 m) known to have high population density and where the reproductive 


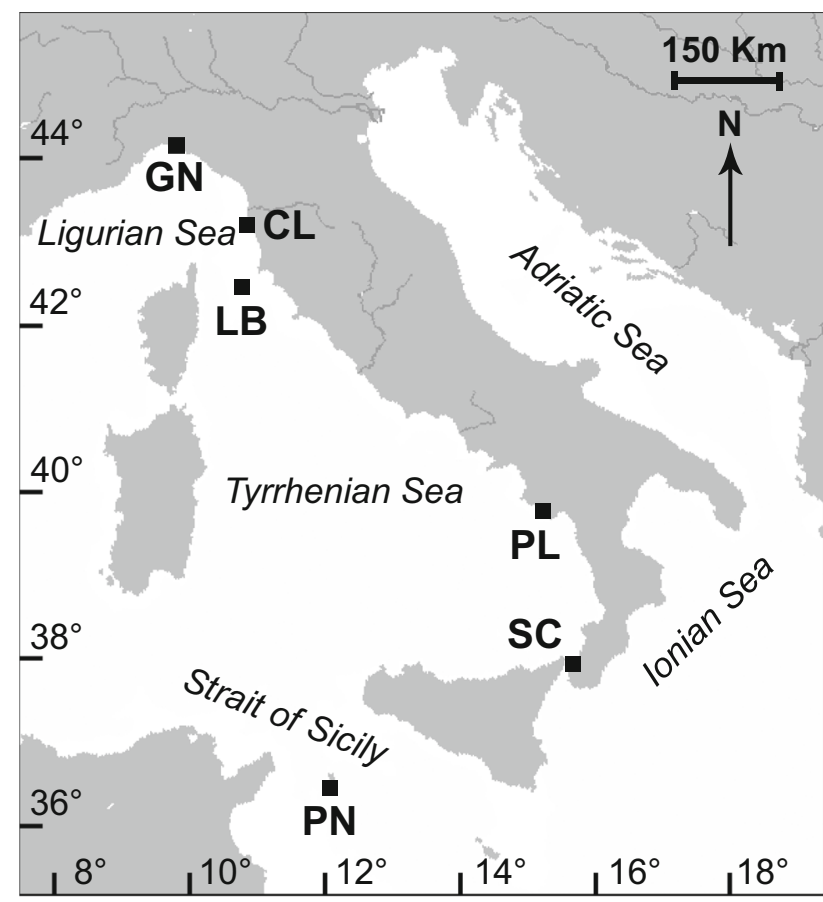

Fig. 1 Map of the Italian coastline indicating the sites where the corals were collected. Abbreviations and coordinates of the site in decreasing order of latitude: GN Genova, $44^{\circ} 20^{\prime} \mathrm{N}, 9^{\circ} 08^{\prime} \mathrm{E}$; CL Calafuria, $43^{\circ} 27^{\prime} \mathrm{N}, 10^{\circ} 21^{\prime} \mathrm{E}$; LB Elba Isle, $42^{\circ} 45^{\prime} \mathrm{N}, 10^{\circ} 24^{\prime} \mathrm{E}$; PL Palinuro, $40^{\circ} 02^{\prime} \mathrm{N}, 15^{\circ} 16^{\prime} \mathrm{E}$; SC Scilla, $38^{\circ} 01^{\prime} \mathrm{N}, 15^{\circ} 38^{\prime} \mathrm{E}$; PN Pantelleria Isle, $36^{\circ} 45^{\prime} \mathrm{N}, 11^{\circ} 57^{\prime} \mathrm{E}$

biology (Goffredo et al. 2012a), biometry and abundance (Caroselli et al. 2015), and growth and population demography have been studied (Caroselli et al. 2016). Patches were sampled on the vault of crevices, except at the Elba site, where samples were collected under the wings of a sunken plane wreck. All of the polyps found within each patch were collected.

Collected corals were dried at $50{ }^{\circ} \mathrm{C}$ for $4 \mathrm{~d}$, then fragments of substratum and calcareous deposits produced by other organisms were removed after observation under binocular microscope. A low drying temperature was chosen to avoid phase transitions in the skeletal aragonite/calcite composition (Vongsavat et al. 2006; Goffredo et al. 2012b). Corallite length ( $L$ : maximum axis of the oral disk), width ( $W$ : minimum axis of the oral disk) and height ( $h$ : oral-aboral axis) were measured using calipers, and dry skeletal mass $(M)$ was measured using a precision balance (Goffredo and Chadwick-Furman 2003). Corallite volume $(V)$ was determined by applying the formula (Goffredo et al. 2007, 2008)

$V=\frac{L}{2} \times \frac{W}{2} \times h \pi$

The bulk skeletal density (Bucher et al. 1998) of each individual was obtained by dividing $M$ by $V$. The age of each sample was estimated using the von Bertalanffy length-age growth function, previously obtained and based on growth band analysis by means of computerized tomography (von Bertalanffy 1938; Sparre et al. 1989; Caroselli et al. 2012, 2016). Using the von Bertalanffy length-age growth function to estimate the age of the polyp, the annual linear extension rate was obtained for each sample (von Bertalanffy 1938; Caroselli et al. 2012). The mean annual net calcification rate (mass of $\mathrm{CaCO}_{3}$ deposited per year per area unit) was calculated for each sample by the formula: net calcification rate $\left(\mathrm{mg} \mathrm{mm} \mathrm{m}^{-2} \mathrm{yr}^{-1}\right)=$ bulk skeletal density $\left(\mathrm{mg} \mathrm{mm}^{-3}\right) \times$ linear extension rate $\left(\mathrm{mm} \mathrm{yr}^{-1}\right)$ (Lough and Barnes 2000; Carricart-Ganivet 2004; Goffredo et al. 2009; Caroselli et al. 2012). Thus, for each population the mean bulk skeletal density, linear extension rate and net calcification rate of each coral were calculated. Samples were divided into three age classes: immature $(0-7 \mathrm{yr}$, after Marchini et al. 2015), mature (7-14 yr, double the age at sexual maturity) and old ( $>14 \mathrm{yr}$ ). Correlation and regression analyses between environmental and growth parameters were performed for the three age classes (Goffredo et al. 2009; Caroselli et al. 2012). Relationships between environmental and growth parameters were investigated using two models: a linear model and a power function model. The linear model was used to compare the results with other studies on environmental controls of coral growth that used linear functions (Lough and Barnes 2000; Carricart-Ganivet 2004; Goffredo et al. 2009; Caroselli et al. 2012). The power function model was used because it produced the best fit with the data, as occurred for other Mediterranean species (see Goffredo et al. 2009; Caroselli et al. 2012). The power function model:

$y=a x^{b}$

was linearized with a log transformation of both the independent and dependent variables, producing the equation:

$\ln (y)=b \ln (x)+\ln (a)$

In this study, the environmental parameters (DT and SR) for each site were obtained by averaging monthly values that covered the mean turnover time of the populations, found to be $6 \mathrm{yr}$ (Caroselli et al. 2016). Thus, 72 monthly values were considered for each site, starting from the sampling month backward. With this method, the mean environmental parameter values considered where those experienced by the polyps for most of their lifespan. Physical measurement data were obtained from data banks, as commonly done by several authors to study the influence of the environmental parameters on coral growth (e.g., Lough and Barnes 2000; Carricart-Ganivet 2004; Cantin et al. 2010; Harriott 1999; Peirano et al. 1999, 2005a, b).

Temperature data $\left({ }^{\circ} \mathrm{C}\right)$ were recorded by three digital thermometers (i-Button, DS1921G-F5\#, Maxim Integrated 
Products, Dallas Semiconductors) that were placed at the experimental sites and recorded seawater temperature every $2-3 \mathrm{~h}$ during time intervals depending on the site. Thermometers were replaced every 3 months to avoid problems of encrustation and overgrowth by marine organisms. SST historical data $\left({ }^{\circ} \mathrm{C}\right)$ were obtained for each site from the National Mareographic Network of the Superior Institute for the Environmental Protection and Research (ISPRA; http://isprambiente.gov.it). These data are measured by SM3810 mareographic stations placed close to the sampling sites and produced by the Society for Environmental and Industrial Monitoring (SIAP + MICROS). Site-by-site, historical at-depth temperatures were estimated by linear regression produced between DT and SST. In this study, the average DT of the $6 \mathrm{yr}$ preceding the sampling ( $n=72$ monthly temperatures) was considered.

Monthly values of SR $\left(\mathrm{W} \mathrm{m}^{-2}\right)$ were obtained from the databank of the Satellite Application Facility on Climate Monitoring (CM-SAF/EUMETSAT; http://www.cmsaf. eu). These are estimates derived from real-time satellite measurements and data sets registered with intersensorcalibrated radiances. Mean annual SR was calculated for the $15-\mathrm{km}$ square associated with each study site by averaging 72 monthly values.

When assumptions for parametric statistics were met, analysis of variance (ANOVA) was used to compare groups of means. Otherwise, the Kruskal-Wallis test (Potvin and Roff 1993) was used to compare mean age, bulk skeletal density, linear extension rate and net calcification rate among populations. Pearson's correlation coefficients were calculated to test the relationship within mean growth parameters and between environmental and mean growth parameters. Given the low sample size $(n=6)$ and the assumptions of the Pearson method, correlation coefficients were also estimated with a bootstrapping procedure (Efron 1981), with 1000 resamples. A multiple regression was run to predict the net calcification rate from linear extension rate and bulk skeletal density. All analyses were computed using IBM SPSS Statistic 22.0.

\section{Results}

Linear regressions between SST and DT were significant at each site (Pearson's correlation, $p<0.001$ ) allowing the calculation of the mean DT along the turnover time period for each site. In the investigated latitudinal range, DT and SR varied by $2.41{ }^{\circ} \mathrm{C}$ and $52.47 \mathrm{~W} \mathrm{~m}^{-2}$, respectively (Table 1). DT and SR both varied among sites (ANOVA, $p<0.01)$. While SR was negatively correlated with latitude (Pearson's correlation, $p<0.001$ ), DT was not correlated with latitude (Pearson's correlation, $p>0.05$ ).
Mean age, net calcification rate, linear extension rate and bulk skeletal density (Table 2) were significantly different among populations (Kruskal-Wallis test, $p<0.001$ ). While mean linear extension rate and mean bulk skeletal density were not correlated with each other, they were both significantly correlated with the mean net calcification rate (Table 3 ). These variables predicted the net calcification rate $(F$ test, $p<0.001)$ explaining $99 \%$ of variance in net calcification rate. The result of the multiple regression was:

$$
\begin{aligned}
\text { Net calcification rate }= & 0.852 \times \text { Bulk skeletal density } \\
& +1.201 \times \text { Linear extension rate }-0.996
\end{aligned}
$$

The age stratification analysis (Tables 4,5 ) found no relationship between growth and environmental parameters in mature and old individuals (no old individuals were found at Genova and Calafuria, so sample size for the correlations of old individuals was 4; Tables 4 and 5). For immature individuals and based on bootstrapping coefficients, SR correlated negatively with linear extension rate in both the linear and power function models (Pearson's correlation, $p<0.05$ ), and DT correlated negatively with net calcification rate (Pearson's correlation, $p<0.05$ ). Excluding the Calafuria dataset from the analysis, the correlation between DT and immature net calcification rate was not significant $(n=5$, Pearson's correlation, $p>0.05)$.

\section{Discussion}

The mean growth parameter values found in this study were similar to previous studies. In fact, calculated bulk skeletal densities were comparable with the values found for other tropical and temperate species (Lough and Barnes 2000; Carricart-Ganivet 2004; Goffredo et al. 2009; Tanzil et al. 2009; Caroselli et al. 2012). Moreover, the average linear extension rate for French and Spanish $C$. inornata populations $\left(0.68 \mathrm{~mm} \mathrm{yr}^{-1}\right.$; Teixido et al. 2011) falls within the range found in this study $\left(0.63-0.90 \mathrm{~mm} \mathrm{yr}^{-1}\right.$; Table 2).

A coral's growth strategy is the mechanism through which it can preferentially invest calcification resources between thickening the skeleton (increasing skeletal density) and accelerating linear extension. For example, two tropical zooxanthellate corals show different growth patterns: while Porites sp. allocates enhanced calcification into linear extension (Lough and Barnes 2000), Orbicella annularis allocates calcification resources into denser skeletons (Carricart-Ganivet 2004). In the Mediterranean Sea, the zooxanthellate colonial coral $C$. caespitosa shows a similar strategy to massive Porites (Kružić et al. 2012). 
Table 1 Values of sampling depth temperature (DT) and solar radiation (SR) at each site

\begin{tabular}{lllll}
\hline Site & Code & Latitude & $\begin{array}{l}\text { Depth temperature }\left({ }^{\circ} \mathrm{C}\right), \\
\text { annual mean (SE) }\end{array}$ & $\begin{array}{l}\text { Solar radiation }\left(\mathrm{W} \mathrm{m}^{-2}\right), \\
\text { annual mean }(\mathrm{SE})\end{array}$ \\
\hline Calafuria & $\mathrm{CL}$ & $43^{\circ} 27^{\prime} \mathrm{N}$ & $16.74(0.38)$ & $174.88(10.59)$ \\
Elba & $\mathrm{LB}$ & $42^{\circ} 45^{\prime} \mathrm{N}$ & $17.63(0.38)$ & $183.45(10.64)$ \\
Scilla & $\mathrm{SC}$ & $38^{\circ} 01^{\prime} \mathrm{N}$ & $18.20(0.41)$ & $203.22(10.44)$ \\
Genova & $\mathrm{GN}$ & $44^{\circ} 20^{\prime} \mathrm{N}$ & $18.24(0.45)$ & $161.77(9.35)$ \\
Palinuro & $\mathrm{PL}$ & $40^{\circ} 02^{\prime} \mathrm{N}$ & $18.94(0.44)$ & $194.94(10.78)$ \\
Pantelleria & $\mathrm{PN}$ & $36^{\circ} 45^{\prime} \mathrm{N}$ & $19.15(0.41)$ & $214.23(10.17)$
\end{tabular}

DT and SR both varied among the sites (Kruskal-Wallis test, $p<0.001$ ). Sites are arranged in increasing order of DT. SE standard error

Table 2 Mean age, bulk skeletal density, linear extension rate and net calcification rate of populations Caryophyllia inornata at six sites in Italy

\begin{tabular}{llrllll}
\hline Site & Code & $\mathrm{n}$ & $\begin{array}{l}\text { Age }(\mathrm{yr}), \\
\text { mean }(\mathrm{SE})\end{array}$ & $\begin{array}{l}\text { Bulk skeletal density } \\
\left(\mathrm{mg} \mathrm{mm}^{-3}\right), \text { mean }(\mathrm{SE})\end{array}$ & $\begin{array}{l}\text { Linear extension rate } \\
\left(\mathrm{mm} \mathrm{yr}^{-1}\right), \text { mean }(\mathrm{SE})\end{array}$ & $\begin{array}{l}\text { Net calcification rate } \\
\left(\mathrm{mg} \mathrm{mm}^{-2} \mathrm{yr}^{-1}\right), \mathrm{mean}_{(\mathrm{SE})}\end{array}$ \\
\hline Calafuria & $\mathrm{CL}$ & 62 & $3.29(0.19)$ & $1.64(0.11)$ & $0.90(0.01)$ & $1.50(0.11)$ \\
Elba & LB & 241 & $6.52(0.26)$ & $1.24(0.04)$ & $0.74(0.01)$ & $0.92(0.04)$ \\
Scilla & SC & 47 & $8.28(0.56)$ & $1.16(0.04)$ & $0.65(0.02)$ & $0.76(0.04)$ \\
Genova & GN & 86 & $4.58(0.29)$ & $0.99(0.03)$ & $0.83(0.02)$ & $0.84(0.04)$ \\
Palinuro & PL & 93 & $8.45(0.41)$ & $0.97(0.02)$ & $0.63(0.03)$ & $0.63(0.03)$ \\
Pantelleria & PN & 39 & $8.81(0.67)$ & $1.11(0.05)$ & $0.70(0.05)$ \\
\hline
\end{tabular}

Sites are arranged in order of increasing depth temperature. $n$ number of individuals, $S E$ standard error

Table 3 Linear regression and correlation analysis between mean bulk skeletal density, linear extension rate and net calcification rate of Caryophyllia inornata at six sites $(n=6)$

\begin{tabular}{|c|c|c|c|c|c|c|c|}
\hline Dependent variable & Independent variable & Slope (SE) & Intercept (SE) & $r^{2}$ & $r$ & $r_{\mathrm{BS}}^{2}$ & $r_{\mathrm{BS}}$ \\
\hline Bulk skeletal density & Linear extension rate & - & - & 0.401 & 0.633 & 0.211 & 0.459 \\
\hline Net calcification rate & Linear extension rate & $2.344(0.706)$ & $-0.821(0.521)$ & 0.734 & $0.857^{*}$ & 0.727 & $0.853 *$ \\
\hline Net calcification rate & Bulk skeletal density & $1.211(0.225)$ & $-0.544(0.271)$ & 0.879 & $0.938 * *$ & 0.665 & $0.816^{*}$ \\
\hline
\end{tabular}

$r^{2}=$ Pearson's coefficient of determination, $r=$ Pearson's correlation coefficient, $r_{\mathrm{BS}}^{2}$ and $r_{\mathrm{BS}}=$ Pearson's coefficients calculated with bootstrapping, $S E$ standard error

$* p<0.05 ; * * p<0.01$

The three growth parameters have been investigated in only two solitary corals, the azooxanthellate $L$. pruvoti (Caroselli et al. 2012) and the zooxanthellate B. europaea (Goffredo et al. 2009). The net calcification rate of $L$. pruvoti responds in a similar way to the tropical $M$. annularis, with calcification resources preferentially allocated to increasing bulk skeletal density (Caroselli et al. 2012). The endemic B. europaea allocates calcification evenly between linear extension and skeletal density, as the mechanical strength of the skeleton and the ability to colonize new substratum quickly are equally important for this species (Goffredo et al. 2009). Caryophyllia inornata behaved in a similar way to B. europaea, with a balanced modulation of skeletal growth. Net calcification rate correlated positively with both linear extension rate and bulk skeletal density, which did not correlate with each other. Multiple regression showed that the net calcification rate of this species was significantly described by both linear extension rate and bulk skeletal density (Eq. 4). Thus, the pattern suggests that fast colonization of new substratum and the strength of the corallite against mechanical stress are also both important for $C$. inornata, as illustrated by the Elba population. In fact, the habitat normally occupied by C. inornata is also colonized by L. pruvoti (Teixido et al. 2011), which is normally present in higher densities in the crevices of the study sites (Caroselli et al. 2012, 2015). However, $C$. inornata is the only coral present at the Elba sampling site under the wings of the sunken plane wreck and it is present with unusually high abundance (Caroselli et al. 2015). A possible explanation could be that $C$. inornata may invest more calcification resources in linear extension than L. pruvoti, which deploys most calcification resources in increasing skeletal thickness. This could result in better performance when colonizing unoccupied space 
Table 4 Linear regression and correlation analysis between mean environmental ( $S R$ solar radiation, $D T$ depth temperature) and growth parameters of Caryophyllia inornata at six sites using a linear model

\begin{tabular}{|c|c|c|c|c|c|c|c|}
\hline Dependent variable & Independent variable & Slope (SE) & Intercept (SE) & $r^{2}$ & $r$ & $r_{\mathrm{BS}}^{2}$ & $r_{\mathrm{BS}}$ \\
\hline \multicolumn{8}{|c|}{ Immature individuals $(0-6 \mathrm{yr}, n=6)$} \\
\hline Skeletal density & SR & - & - & 0.099 & -0.315 & 0.067 & -0.259 \\
\hline Linear extension & SR & $-0.002(0.001)$ & $1.196(0.123)$ & 0.664 & $-0.815^{*}$ & 0.684 & $-0.827 *$ \\
\hline Calcification & SR & - & - & 0.133 & -0.365 & 0.130 & -0.360 \\
\hline Skeletal density & DT & - & - & 0.707 & $-0.841 *$ & 0.513 & -0.716 \\
\hline Linear extension & DT & - & - & 0.654 & -0.809 & 0.581 & -0.762 \\
\hline Calcification & DT & $-0.252(0.059)$ & $5.633(1.065)$ & 0.823 & $-0.907 *$ & 0.796 & $-0.892 *$ \\
\hline \multicolumn{8}{|c|}{ Mature individuals (7-13 yr, $n=6$ ) } \\
\hline Skeletal density & SR & - & - & 0.002 & 0.041 & 0.000 & 0.021 \\
\hline Linear extension & SR & - & - & 0.518 & -0.720 & 0.557 & -0.746 \\
\hline Calcification & SR & - & - & 0.033 & -0.183 & 0.011 & -0.104 \\
\hline Skeletal density & DT & - & - & 0.533 & -0.730 & 0.397 & -0.630 \\
\hline Linear extension & DT & - & - & 0.596 & -0.772 & 0.461 & -0.679 \\
\hline Calcification & DT & - & - & 0.689 & $-0.830 *$ & 0.493 & -0.702 \\
\hline \multicolumn{8}{|c|}{ Old individuals ( $>13 \mathrm{yr}, n=4)$} \\
\hline Skeletal density & SR & - & - & 0.077 & -0.278 & 0.086 & -0.293 \\
\hline Linear extension & SR & - & - & 0.008 & 0.089 & 0.000 & -0.018 \\
\hline Calcification & SR & - & - & 0.046 & -0.215 & 0.012 & -0.109 \\
\hline Skeletal density & DT & - & - & 0.656 & -0.810 & 0.635 & -0.797 \\
\hline Linear extension & DT & - & - & 0.085 & 0.292 & 0.076 & 0.275 \\
\hline Calcification & DT & - & - & 0.299 & -0.547 & 0.200 & -0.447 \\
\hline
\end{tabular}

$r^{2}=$ Pearson's coefficient of determination, $r=$ Pearson's correlation coefficient, $r_{\mathrm{BS}}^{2}$ and $r_{\mathrm{BS}}=$ Pearson's coefficients calculated with bootstrapping, $S E$ standard error

$* p<0.05$

such as a recently sunk wreck. Besides that, reproduction in C. inornata could also benefit from this kind of modulation, as the size at sexual maturity can be achieved quickly. Moreover, the possible asexual reproduction that characterizes this species (Goffredo et al. 2012a, b) could be another factor favoring $C$. inornata in comparison with $L$. pruvoti, which does not reproduce asexually. However, this interpretation should be treated with caution because this caryophylliid may possibly tolerate the non-natural metallic substratum better than L. pruvoti, which could be linked to aspects other than calcification. In fact, even though $C$. inornata was the only coral found under the wings, L. pruvoti was dominant in the nearby crevices (E. Caroselli, personal observation).

The age stratification analyses did not reveal any correlation between growth of mature and old individuals and environmental parameters. The negative correlation between SR and linear extension rate for immature individuals, confirmed both by the linear and the power function model based on bootstrapped coefficients, may be due to the increasing mean age of immature individuals in the southernmost populations, i.e., the populations with the lowest SR. In fact, the linear extension rate of this species decreases with increasing age (Caroselli et al. 2016), and the mean immature age is higher at lower latitudes (Pearson's correlation test, $p<0.05)$. Consequently, this result is likely to be biased by the slightly higher age of immature individuals in populations characterized by higher SR.

The negative correlation between DT and net calcification rate based on bootstrapped coefficients suggests that calcification of immature individuals decreased with increasing temperature. However, if the Calafuria data were excluded from the analysis, the correlation became insignificant. The Calafuria site is characterized by a high abundance of zooplankton (Santangelo et al. 2009; Saiz et al. 2014) that is likely to enhance the calcification rate (Ferrier-Pagès et al. 2003; Naumann et al. 2011), explaining the higher level of net calcification rate at this site compared to all the others. However, the trend was observed only for immature individuals, which could be explained by a different energy allocation strategy during the lifespan of the individuals. An immature polyp at Calafuria could benefit from the additional energy coming from zooplankton by allocating it to the calcification process, thus increasing linear extension (to achieve the size at sexual maturity) and skeletal density (to strengthen the first 
Table 5 Linear regression and correlations analysis between mean environmental ( $S R$ solar radiation, $D T$ depth temperature) and growth parameters of Caryophyllia inornata at six sites using a linearized power function model (Eq. 3)

\begin{tabular}{|c|c|c|c|c|c|c|c|}
\hline Dependent variable & Independent variable & Slope (SE) & Intercept (SE) & $r^{2}$ & $r$ & $r_{\mathrm{BS}}^{2}$ & $r_{\mathrm{BS}}$ \\
\hline \multicolumn{8}{|c|}{ Immature individuals ( $0-6 \mathrm{yr}, n=6)$} \\
\hline Skeletal density & SR & - & - & 0.081 & -0.284 & 0.044 & -0.209 \\
\hline Linear extension & SR & $-0.396(0.141)$ & $1.914(0.741)$ & 0.663 & $-0.814^{*}$ & 0.667 & $-0.817 *$ \\
\hline Calcification & SR & - & - & 0.120 & -0.346 & 0.095 & -0.309 \\
\hline Skeletal density & DT & - & - & 0.726 & $-0.852 *$ & 0.524 & -0.724 \\
\hline Linear extension & DT & - & - & 0.648 & -0.805 & 0.530 & -0.728 \\
\hline Calcification & DT & $-3.953(0.786)$ & $11.481(2.278)$ & 0.863 & $-0.929 * *$ & 0.815 & $-0.903 *$ \\
\hline \multicolumn{8}{|c|}{ Mature individuals $(7-13 \mathrm{yr}, n=6)$} \\
\hline Skeletal density & SR & - & - & 0.024 & 0.154 & 0.009 & 0.096 \\
\hline Linear extension & SR & - & - & 0.537 & -0.733 & 0.516 & -0.718 \\
\hline Calcification & SR & - & - & 0.010 & -0.100 & 0.002 & -0.042 \\
\hline Skeletal density & DT & - & - & 0.465 & -0.682 & 0.364 & -0.603 \\
\hline Linear extension & DT & - & - & 0.599 & -0.774 & 0.479 & -0.692 \\
\hline Calcification & DT & - & - & 0.672 & $-0.820 *$ & 0.479 & -0.692 \\
\hline \multicolumn{8}{|c|}{ Old individuals ( $>13 \mathrm{yr}, n=6)$} \\
\hline Skeletal density & SR & - & - & 0.028 & -0.167 & 0.040 & -0.201 \\
\hline Linear extension & SR & - & - & 0.003 & 0.059 & 0.004 & 0.060 \\
\hline Calcification & SR & - & - & 0.009 & -0.097 & 0.000 & 0.005 \\
\hline Skeletal density & DT & - & - & 0.588 & -0.767 & 0.570 & -0.755 \\
\hline Linear extension & DT & - & - & 0.078 & 0.279 & 0.094 & 0.307 \\
\hline Calcification & DT & - & - & 0.279 & -0.528 & 0.173 & -0.416 \\
\hline
\end{tabular}

$n=$ number of populations, $r^{2}=$ Pearson's coefficient of determination, $r=$ Pearson's correlation coefficient, $r_{\mathrm{BS}}^{2}$ and $r_{\mathrm{BS}}=$ Pearson's coefficients calculated with bootstrapping, $S E$ standard error

$* p<0.05 ; * * p<0.01$

skeletal elements). As they age, these individuals could alter their investment of surplus energy to the costly reproductive process that characterizes this species (Marchini et al. 2015). Consequently, the statistically significant correlation between calcification and SR for immature individuals is not likely to describe a true dependence on temperature variation along the gradient, but is probably due to the local trophic conditions characterizing Calafuria.

These responses to temperature variations have also been observed for the only other azooxanthellate coral studied in the Mediterranean (L. pruvoti; Caroselli et al. 2012) and contrast with zooxanthellate species in both the tropics (Porites sp.: Lough and Barnes 2000; O. annularis: Carricart-Ganivet 2004; and Diploastrea heliopora: Cantin et at. 2010) and in the Mediterranean Sea (B. europaea: Goffredo et al. 2009; and C. caespitosa: Kružić et al. 2012). In zooxanthellate corals, the relationship between calcification and temperature is thought to be linked to the response of photosynthesis by zooxanthellae to temperature (Goffredo et al. 2009; Cantin et al. 2010). In fact, calcification is enhanced by photosynthesis in tropical systems (Al-Horani et al. 2005), where calcification is positively correlated with SST, for example, for Porites sp. in the Great Barrier Reef and $O$. annularis in the Caribbean (Lough and Barnes 2000; Carricart-Ganivet 2004). In contrast, in the Red Sea, D. heliopora shows a decrease in net calcification and linear extension rates with increased SST, assuming constant inferred bulk density (Cantin et al. 2010). However, a recent study demonstrated that coral net calcification rate increased to a maximum and declined afterward, with different sensitivity among species (Carricart-Ganivet et al. 2012). For example, in Orbicella sp. net calcification decreased more moderately than in Porites sp., leading to the hypothesis that changes in reef-building community composition - where the majority of species are zooxanthellate-are likely to happen under predicted global warming scenarios (Carricart-Ganivet et al. 2012). Furthermore, in zooxanthellate corals calcification also decreases in suboptimal thermal conditions (HoeghGuldberg et al. 2007) and under high temperature stress (Rodolfo-Metalpa et al. 2006; Cooper et al. 2008; Tanzil et al. 2009; Cantin et al. 2010), emphasizing concern for these species. In temperate seas, particularly the Mediterranean Sea, net calcification rate variations with 
environmental parameters have been investigated in only a few species (Caroselli and Goffredo 2014). Net calcification of the endemic B. europaea and C. caespitosa is temperature dependent, while in the azooxanthellate $L$. pruvoti and $C$. inornata net calcification is unaffected by temperature. In particular, while net calcification rate of C. caespitosa is positively correlated with SST (Kružić et al. 2012), net calcification of B. europaea has the opposite trend (Goffredo et al. 2009).

The previously formulated hypothesis that azooxanthellate Mediterranean scleractinians have a higher tolerance to high temperature than zooxanthellate corals (Caroselli and Goffredo 2014) is supported by the present findings and by previous studies on other biological parameters of $C$. inornata (such as population abundance, mortality and population structure stability) which are not related to temperature variations (Caroselli et al. 2015, 2016). It can be argued that an adaptive shift in the symbiont community may promote higher resilience (Baker et al. 2004; Fitt et al. 2009), and thus, zooxanthellate scleractinians could enhance their temperature tolerance. Nevertheless, there have been no studies in temperate environments on symbiont community shifts; in addition, the clades of Symbiodinium sp. reported in Mediterranean corals do not include the clades demonstrated to be more high-temperature-tolerant (Baker et al. 2004; Visram et al. 2006; Fitt et al. 2009).

This study adds knowledge about the response of poorly studied azooxanthellate corals in the Mediterranean Sea and supports concerns for zooxanthellate species in the face of global warming. However, these results should not be generalized broadly since this is the first investigation of the relationship between two major environmental parameters and growth parameters of a caryophylliid coral, and other species may show different tolerance to temperature increases.

In conclusion, it was observed that (1) net calcification rate correlated positively both with bulk skeletal density and linear extension rate, and (2) C. inornata appears to be tolerant to the natural range of DT and SR experienced in the field.

Acknowledgments Thanks to S. Branchini, F. Gizzi, M. Marinozzi, S. Prantoni and F. Turano for their underwater help and assistance during the sampling procedure. The diving centers Centro Immersioni Pantelleria, Il Pesciolino, Bubble Lounge and Sub Maldive supplied logistic assistance in the field. The Scientific Diving School (www. sdseducational.org) supplied technical and logistical support. The research leading to these results has received funding from the European Research Council under the European Union's Seventh Framework Programme (FP7/2007-2013)/ERC grant agreement $n^{\circ}$ [249930-CoralWarm: Corals and global warming: the Mediterranean versus the Red Sea]. The experiment complied with current Italian law.

\section{References}

Airi V, Gizzi F, Falini G, Levy O, Dubinsky Z, Goffredo S (2014) Reproductive efficiency of a Mediterranean endemic zooxanthellate coral decreases with increasing temperature along a wide latitudinal gradient. PLoS One 9:e91792

Al-Horani FA, Ferdelman T, Al-Moghrabi SM, de Beer D (2005) Spatial distribution of calcification and photosynthesis in the scleractinian coral Galaxea fascicularis. Coral Reefs 24:173-180

Anthony KRN, Kerswell AP (2007) Coral mortality following extreme low tides and high solar radiation. Mar Biol 151:1623-1631

Baker AC, Starger CJ, McClanahan TR, Glynn PW (2004) Coral reefs: corals' adaptive response to climate change. Nature 430:741

Brown BE, Dunne RP, Goodson MS, Douglas AE (2000) Marine ecology: bleaching patterns in reef corals. Nature 404:142-143

Bucher DJ, Harriott VJ, Roberts LG (1998) Skeletal micro-density, porosity and bulk density of acroporid corals. J Exp Mar Bio Ecol 228:117-136

Budd AF, Fukami H, Smith ND, Knowlton N (2012) Taxonomic classification of the reef coral family Mussidae (Cnidaria: Anthozoa: Scleractinia). Zool J Linn Soc 166:465-529

Cantin NE, Cohen AL, Karnauskas KB, Tarrant AM, McCorkle DC (2010) Ocean warming slows coral growth in the central red sea. Science 329:322-325

Caroselli E, Goffredo S (2014) Mediterranean coral population dynamics: a tale of 20 years of field studies. In: Goffredo S, Dubinsky Z (eds) The Mediterranean Sea: its history and present challenges. Springer Science + Business Media BV, Dordrecht, pp 275-284

Caroselli E, Mattioli G, Levy O, Falini G, Dubinsky Z, Goffredo S (2012) Inferred calcification rate of a Mediterranean azooxanthellate coral is uncoupled with sea surface temperature along an $8^{\circ}$ latitudinal gradient. Front Zool 9:32

Caroselli E, Nanni V, Levy O, Falini G, Dubinsky Z, Goffredo S (2015) Latitudinal variations in biometry and population density of a Mediterranean solitary coral. Limnol Oceanogr 60:1356-1370

Caroselli E, Ricci F, Brambilla V, Mattioli G, Levy O, Falini G, Dubinsky Z, Goffredo S (2016) Relationships between growth, population dynamics, and environmental parameters in the solitary non-zooxanthellate scleractinian coral Caryophyllia inornata along a latitudinal gradient in the Mediterranean Sea. Coral Reefs. doi:10.1007/s00338-015-1393-9

Carricart-Ganivet JP (2004) Sea surface temperature and the growth of the West Atlantic reef-building coral Montastraea annularis. J Exp Mar Bio Ecol 302:249-260

Carricart-Ganivet JP (2007) Annual density banding in massive coral skeletons: result of growth strategies to inhabit reefs with high microborers' activity? Mar Biol 153:1-5

Carricart-Ganivet JP, Merino M (2001) Growth responses of the reefbuilding coral Montastraea annularis along a gradient of continental influence in the southern Gulf of Mexico. Bull Mar Sci 68:133-146

Carricart-Ganivet JP, Cabanillas-Teràn N, Cruz-Ortega I, Blanchon P (2012) Sensitivity of calcification to thermal stress varies among genera of massive reef-building corals. PLoS One 7:e32859

Coma R, Ribes M, Gili JM, Zabala M (2000) Seasonality in coastal benthic ecosystems. Trends Ecol Evol 15:448-453

Cooper TF, De'Ath G, Fabricius KE, Lough JM (2008) Declining coral calcification in massive Porites in two nearshore regions of the northern Great Barrier Reef. Glob Chang Biol 14:529-538

Dodge RE, Brass GW (1984) Skeletal extension, density and calcification of the reef coral, Montastrea annularis: St. Croix, U.S. Virgin Islands. Bull Mar Sci 34:288-307 
Efron B (1981) Nonparametric estimates of standard error: the jackknife, the bootstrap and other methods. Biometrika 68:589599

Ferrier-Pagès C, Witting J, Tambuttè E, Sebens KP (2003) Effect of natural zooplankton feeding on the tissue and skeletal growth of the scleractinian coral Stylophora pistillata. Coral Reefs 22:229240

Fitt WK, Gates RD, Hoegh-Guldberg O, Bythell JC, Jatkar A, Grottoli AG, Gomez M, Fisher P, LaJeunesse TC, Pantos O, Iglesias-Prieto R, Franklin DJ, Rodrigues LJ, Torregiani JM, van Woesik R, Lesser MP (2009) Response of two Indo-Pacific corals, Porites cylindrica and Stylophora pistillata to short-term thermal stress: the host does matter in determining the tolerance of corals to bleaching. J Exp Mar Bio Ecol 373:102-110

Goffredo S, Chadwick-Furman NE (2003) Comparative demography of mushroom corals (Scleractinia, Fungiidae) at Eilat, northern Red Sea. Mar Biol 142:411-418

Goffredo S, Lasker HR (2008) An adaptive management approach to an octocoral fishery based on the Beverton-Holt model. Coral Reefs 27:751-761

Goffredo S, Caroselli E, Pignotti E, Mattioli G, Zaccanti F (2007) Variation in biometry and population density of solitary corals with solar radiation and sea surface temperature in the Mediterranean Sea. Mar Biol 152:351-361

Goffredo S, Caroselli E, Mattioli G, Pignotti E, Zaccanti F (2008) Relationships between growth, population structure and sea surface temperature in the temperate solitary coral Balanophyllia europaea (Scleractinia, Dendrophylliidae). Coral Reefs 27:623632

Goffredo S, Caroselli E, Mattioli G, Pignotti E, Dubinsky Z, Zaccanti $F$ (2009) Inferred level of calcification decreases along an increasing temperature gradient in a Mediterranean endemic coral. Limnol Oceanogr 54:930-937

Goffredo S, Marchini C, Rocchi M, Airi V, Caroselli E, Falini G, Levy O, Dubinsky Z, Zaccanti F (2012a) Unusual pattern of embryogenesis of Caryophyllia inornata (Scleractinia, Caryophylliidae) in the Mediterranean Sea. Maybe agamic reproduction? J Morphol 273:943-956

Goffredo S, Caroselli E, Mezzo F, Laiolo L, Vergni P, Pasquini L, Levy O, Zaccanti F, Tribollet A, Dubinsky Z, Falini G (2012b) The puzzling presence of calcite in skeletons of modern solitary corals from the Mediterranean Sea. Geochim Cosmochim Acta $85: 187-199$

Harriott VJ (1999) Coral growth in subtropical eastern Australia. Coral Reefs 15:281-291

Hoegh-Guldberg O (2011) The impact of climate change on coral reef ecosystems. In: Dubinsky Z, Stambler N (eds) Coral reefs: an ecosystem in transition. Springer Science + Business Media BV, Dordrecht, pp 391-403

Hoegh-Guldberg O, Mumby PJ, Hooten AJ, Steneck RS, Greenfield P, Gomez E, Harvell CD, Sale PF, Edwards AJ, Caldeira K, Knowlton N, Eakin CM, Iglesias-Prieto R, Muthiga N, Bradbury RH, Dubi A, Hatziolos ME (2007) Coral reefs under rapid climate change and ocean acidification. Science 318:1737-1742

Howe SA, Marshall AT (2002) Temperature effects on calcification rate and skeletal deposition in the temperate coral, Plesiastrea versipora (Lamark). J Exp Mar Bio Ecol 275:63-81

Kleypas JA, McManus JW, Menez AB (1999) Environmental limits to coral reef development: where do we draw the line? Am Zool 39:146-159

Kleypas JA, Buddemeier RW, Eakin CM, Gattuso J-P, Guinotte J, Hoegh-Guldberg O, Iglesias-Prieto R, Jokiel PL, Langdon C, Skirving W, Strong AE (2005) Comment on "Coral reef calcification and climate change: the effect of ocean warming". Geophys Res Lett 32:L08601
Kružić P, Sršen P, Benković L (2012) The impact of seawater temperature on coral growth parameters of the colonial coral Cladocora caespitosa (Anthozoa, Scleractinia) in the eastern Adriatic Sea. Facies 58:477-491

Lough JM, Barnes DJ (2000) Environmental controls on growth of the massive coral Porites. J Exp Mar Bio Ecol 245:225-243

Lough JM, Cantin NE (2014) Perspectives on massive coral growth rates in a changing ocean. Biol Bull 226:187-202

Marchini C, Airi V, Fontana R, Tortorelli G, Rocchi M, Falini G, Levy O, Dubinsky Z, Goffredo S (2015) Annual reproductive cycle and unusual embryogenesis of a temperate coral in the Mediterranean Sea. PLoS One 10:e0141162

Marshall AT, Clode P (2004) Calcification rate and the effect of temperature in a zooxanthellate and an azooxanthellate scleractinian reef coral. Coral Reefs 23:218-224

Naumann MS, Orejas C, Wild C, Ferrier-Pagès C (2011) First evidence for zooplankton feeding sustaining key physiological processes in a scleractinian cold-water coral. J Exp Biol 214:3570-3576

Peirano A, Morri C, Bianchi CN (1999) Skeleton growth and density pattern of the temperate, zooxanthellate scleractinian Cladocora caespitosa from the Ligurian Sea (NW Mediterranean). Mar Ecol Prog Ser 185:195-201

Peirano A, Damasso V, Montefalcone M, Morri C, Bianchi CN (2005a) Effects of climate, invasive species and anthropogenic impacts on the growth of the seagrass Posidonia oceanica (L.) Delile in Liguria (NW Mediterranean Sea). Mar Pollut Bull 50:817-822

Peirano A, Abbate M, Cerrati G, Difesca V, Peroni C, RodolfoMetalpa R (2005b) Monthly variations in calyx growth, polyp tissue, and density banding of the Mediterranean scleractinian Cladocora caespitosa (L.). Coral Reefs 24:404-409

Potvin C, Roff DA (1993) Distribution-free and robust statistical methods: viable alternatives to parametric statistics? Ecology 74:1617-1628

Reynaud S, Leclercq N, Romaine-Liouds Ferrier-Pagès C, Jaubert J, Gattuso JP (2003) Interacting effects of $\mathrm{CO}_{2}$ partial pressure and temperature on photosynthesis and calcification in a scleractinian coral. Glob Chang Biol 9:1660-1668

Rodolfo-Metalpa R, Richard C, Allemand D, Bianchi CN, Morri C, Ferrier-Pages C (2006) Response of zooxanthellae in symbiosis with the Mediterranean corals Cladocora caespitosa and Oculina patagonica to elevated temperatures. Mar Biol 150:45-55

Saiz E, Sabatés A, Gili JM (2014) The zooplankton. In: Goffredo S, Dubinsky Z (eds) The Mediterranean Sea: its history and present challenges. Springer Science + Business Media BV, Dordrecht, pp 275-284

Santangelo G, Bramanti L, Vielmini I, Iannelli M (2009) What we have learned about red coral and what we need to learn for its rational management. Proceedings of the First International Workshop on Corallium Science, Management, and Trade. NOAA Technical Memorandum NMFS-OPR-43 and CRCP-8, NOAA, Silver Spring, pp 71-86

Shick JM, Lesser MP, Jokiel PL (1996) Effects of ultraviolet radiation on corals and other coral reef organisms. Glob Chang Biol 2:527-545

Sparre P, Ursin E, Siebren C Venema (1989) Introduction to tropical fish stock assessment. FAO Fisheries Technical Paper 306, FAO, Rome

Tanzil JTI, Brown BE, Tudhope AW, Dunne RP (2009) Decline in skeletal growth of the coral Porites lutea from Andaman Sea, south Thailand between 1984 and 2005. Coral Reefs 28:519-528

Teixido N, Garrabou J, Harmelin JG (2011) Low dynamics, high longevity and persistence of sessile structural species dwelling on Mediterranean coralligenous outcrops. PLoS One 6:e23744 
Visram S, Wiedenmann J, Douglas AE (2006) Molecular diversity of symbiotic algae of the genus Symbiodinium (Zooxanthellae) in cnidarians of the Mediterranean Sea. J Mar Biol Assoc UK 86:1281-1283

von Bertalanffy L (1938) A quantitative theory of organic growth (inquiries on growth laws II). Hum Biol 10:181-231

Vongsavat V, Winotai P, Meejoo S (2006) Phase transitions of natural corals monitored by ESR spectroscopy. Nucl Instrum Methods Phys Res B 243:167-173
Walther GR, Post E, Convey P, Menzel A, Parmesan C, Beebee TJC, Fromentin JM, Hoegh-Guldberg O, Bairlein F (2002) Ecological responses to recent climate change. Nature 416:389-395

Zibrowius H (1980) Les scléractiniaires de la Méditeranée et de l'Atlantique nord-oriental. Mémoires de l'Institut océanographique, Monaco 11:1-284 